Article

\title{
Potential Invasion Risk of Pet Traded Lizards, Snakes, Crocodiles, and Tuatara in the EU on the Basis of a Risk Assessment Model (RAM) and Aquatic Species Invasiveness Screening Kit (AS-ISK)
}

\author{
Oldřich Kopecký *, Anna Bílková, Veronika Hamatová, Dominika Kňazovická, Lucie Konrádová, \\ Barbora Kunzová, Jana Slaměníková, Ondřej Slanina, Tereza Šmídová and Tereza Zemancová \\ Department of Zoology and Fisheries, Faculty of Agrobiology, Food and Natural Resources, Czech University of \\ Life Sciences Prague, Kamýcká 129, Praha 6 - Suchdol 165 21, Prague, Czech Republic; \\ annabilkova@email.cz (A.B.); veronikahamatova@seznam.cz (V.H.); dominika.knazovicka@gmail.com (D.K.); \\ lucie.diviakova@gmail.com (L.K.); slamenikova.jana@seznam.cz (J.S.); kunzovab@gmail.com (B.K.); \\ slanina96@seznam.cz (O.S.); terca95@seznam.cz (T.S.); zemancovat@seznam.cz (T.Z.) \\ * Correspondence: kopeckyo@af.czu.cz; Tel.: +420-22438-2955
}

Received: 30 June 2019; Accepted: 9 September 2019; Published: 13 September 2019

\begin{abstract}
Because biological invasions can cause many negative impacts, accurate predictions are necessary for implementing effective restrictions aimed at specific high-risk taxa. The pet trade in recent years became the most important pathway for the introduction of non-indigenous species of reptiles worldwide. Therefore, we decided to determine the most common species of lizards, snakes, and crocodiles traded as pets on the basis of market surveys in the Czech Republic, which is an export hub for ornamental animals in the European Union (EU). Subsequently, the establishment and invasion potential for the entire EU was determined for 308 species using proven risk assessment models (RAM, AS-ISK). Species with high establishment potential (determined by RAM) and at the same time with high potential to significantly harm native ecosystems (determined by AS-ISK) included the snakes Thamnophis sirtalis (Colubridae), Morelia spilota (Pythonidae) and also the lizards Tiliqua scincoides (Scincidae) and Intellagama lesueurii (Agamidae).
\end{abstract}

Keywords: Pet market; Czech Republic; introduction; pathway; ornamental animal; invasive species; snake; lizard; crocodile

\section{Introduction}

Invasive species are considered to be among the major causes of biodiversity loss [1-3], and therefore conservation agencies around the world devote significant attention to this issue [4]. Time, money, and considerable effort are spent each year in the eradication, control and mitigation of non-native species [5]. However, despite the increasing interest of ecologists and conservation biologists in invasions [6], there is no sign that the introduction rate of non-indigenous species is slowing down [7].

In general, vertebrates are introduced more intentionally compared to other organisms [8]. The spread of non-native vertebrates took place in several historically specific waves and different taxonomic groups were at the peak of occupying new territories at different times. Fish, birds and mammals were introduced into new countries mainly in the 19th century and in the second half of the 20th century. On the other hand, the peak of reptile introductions was at the turn of the 20th and 21st centuries [9-11] —although many recent cases may have been overlooked. These differences have been caused by specificity of vectors and reasons for introductions. While fish, birds, and mammals were 
mostly introduced intentionally for the benefit, usually economic, of people [10], the main reason for reptile introductions is the pet trade (which makes up for about $45 \%$ of introductions), which can lead to their subsequent release or escape [12].

Increasing urbanization creates a desire for contact with nature for people living in towns and cities, and keeping pets is one way of fulfilling this need [13]. The popularity of reptiles as pets has been growing steadily since the second half of the 20th century $[14,15]$. Unfortunately, reptiles can have enormous negative ecological impacts, e.g., invasion of the brown tree snake (Boiga irregularis) on Guam island caused the extinction of $77 \%$ of the island's native birds and $75 \%$ of its native lizards [16]. Also, other direct impacts on humans (e.g., (venomous) snakes or power outages caused by these snakes) cost a total of around $\$ 12$ million per year [5]. One of the well-studied reptile invasions through the pet trade pathway in Europe is the case of the pond slider (Trachemys scripta). From 1989 to 1997, 52 million individual pond sliders were exported from the USA to Europe [17]. Because of the massive number of imports, they were sold very cheaply in pet shops. However, the growth of the turtle was associated with the loss of its attractive coloration and an increase in aggression, which often led unexperienced breeders to release them in the wild, where they would compete with native species of freshwater turtles for prey and places for basking $[18,19]$. Also, as a predator they can contribute to a local decline of native invertebrates, fish, or amphibians [20]. It is not surprising, therefore, that the import of T. s. elegans was banned by the EU's Commission Regulation (EC) No 338/97 in 1997 (Official Journal of the European Union, 1997). Regardless of these two examples, reptiles have been widely overlooked in systematic invasion studies [21,22], and their establishment potential and invasion dynamics remain poorly understood [23].

The Czech Republic is the EU hub for the import and export of ornamental animals $[24,25]$, and it is situated between three seas (Black, Baltic and North), which represents significant potential opportunity for the spreading of non-native species into other parts of Europe [26]. In previous articles, we evaluated invasion potential in the European Union for ornamental amphibians [27] and freshwater turtles [28] based on import data and offers from wholesalers from the Czech Republic. In this article, we complete an overview of ornamental herpetofauna by evaluating establishment potential and the impact on native ecosystems for the rest of the reptile taxonomical groups - lizards, snakes, crocodiles, and tuatara.

\section{Materials and Methods}

According to laws and regulations in force in the Czech Republic, the import of live animals and their products is registered by the Customs Administration of the Czech Republic. Therefore, to identify species of reptiles that are being offered in EU countries, we took species listed in materials of the Customs Administration and, additionally, surveyed the online price lists of five leading Czech wholesalers of ornamental animals and domestic producers of these animals to complete the list of potentially invasive reptiles. Furthermore, additional discussions were conducted with wholesalers and producers, who helped us clarify certain queries or provided supplementary information concerning the reptile trade, especially availability on the market. The survey was performed during the year 2016.

Altogether, 381 species from 20 families (Appendix A Table A1) were identified as being on the pet market in the EU. In accordance with Nentwig et al. [29] we restricted our study to species with a native distribution entirely outside the European continent, mainly from different zoogeographical regions.

To stay consistent with previous studies about ectothermic tetrapods, we chose all states of the EU as the target region, while overseas departments and regions of France and Great Britain were not included in our study as parts of the EU $[27,28]$.

We used two hierarchical models for determining the establishment and invasion risk: the Risk Assessment Model (RAM) for exotic amphibians and reptiles developed by the Australian Bureau of Rural Sciences $[21,30]$ and the Aquatic Species Invasiveness Screening Kit v2.0 (AS-ISK) developed by Center for Environment Fisheries and Aquaculture Science (CEFAS) [31]. 
The species identified as being widely traded were firstly assessed by RAM, which tested the probability of their establishment, i.e., the formation of a self-sustaining population in a new environment [32], and then all species were evaluated for their invasion potential, i.e., their spread in the new environment simultaneously producing significant changes in the composition, structure, or processes of the ecosystem [32], in the EU by AS-ISK. We decided to use this approach mainly due to the fact that RAM is a model developed specifically for the determination of establishment only, while a major part of independently scored questions in AS-ISK deals with the potential impacts of an evaluated species rather than its ability to be introduced or established.

RAM is based on four parameters: (i) climatic similarity between the source (native distribution of species) and target regions (termed climate match risk score), (ii) species' abilities to establish populations elsewhere (termed prop.species value), (iii) establishment success of species from the particular family (termed family random effect), and (iv) jurisdiction score, which accounts for expected variability in the establishment success rate due to the effect of a particular jurisdiction (country, state or province) and for all evaluated species is constant.

Climate match risk scores were computed using the program Climatch v1.0 (Bureau of Rural Sciences, 2008) with a Euclidean algorithm and 16 temperature and rainfall variables. This is based on comparison of data from climatic stations in the native range and data from climatic stations in the target region (EU in our case). Values of prop.species scores were computed originally for this study using the Kraus database [12]. When values for calculating prop.species or prop.genus were insufficient, we did not compute a prop.family value [22], but instead used approximation according to phylogenetically related genera i.e., the closest branches on an up-to-date phylogenetic trees. Family random effects were taken from Bomford [30]. If the value of family random effect was not listed, we substituted both potential extremes into the formula (-1.3 and 1.69), and then the range of values for risk score is presented. The risk score in RAM can reach values of $0-1$, where establishment risk ranks are: low $\leq$ 0.16 , moderate $0.17-0.39$, serious $0.40-0.85$ and extreme $\geq 0.86$.

Not all traded species could be evaluated by the described procedure. The main problem was the impossibility of finding a map of occurrence or species living in such a small area which does not contain any climate station. Such species were therefore excluded from our analysis.

AS-ISK is an electronic toolkit which consists of 55 questions [31]. Some of the questions deal with biogeographical similarity, including the climate tolerance of the evaluated species, and some of the questions examine undesirable attributes, such as whether the species is poisonous or if it is a pathogen vector. However, most questions concern the species' biological and ecological characteristics that can facilitate a potential invasion. There are also six questions related to climate change. For evaluating the invasion potential of ornamental reptiles, we used the sum of the scores from the questions dealing with biological and ecological features (this includes undesirable (or persistence) traits, resource exploitation, reproduction, dispersal mechanisms, and tolerance attributes). Because of the character of the questions in the AS-ISK software, we can argue that the AS-ISK invasion score from this part of the program expresses the species' potential abilities to spread in a new environment and to alter the environment either directly or indirectly.

AS-ISK was originally developed for aquatic species. Thus, some questions (23., 44., 45. and 48.) concern characteristics related to life in a water environment. To stay consistent in our evaluation, which covers terrestrial species of reptiles, we used the term "Not applicable" as the answer for these questions across all evaluated species. The categorization (low, medium, or high invasion risk) of final numerical scores is not possible, because we did not use the AS-ISK overall score (i.e., BRA and BRA+CCA scores).

Each author of the article evaluated selected families by using both tools (RAM and AS-ISK). Before the start of the evaluation process, the authors attended three meetings for the unification of procedures and for clarifying specific issues. We searched for publications about the distribution and biology of assessed species, using their scientific names (and if necessary, their older synonyms) as search terms. Furthermore, relevant information provided on websites (www.iucn.org, https: 
//nas.er.usgs.gov, www.animaldiversity.org), as well as literature cited therein, were used to compile published information available on selected species.

\section{Results}

The basics (a distribution map, or the presence of a climatic station in the area of distribution) for a climate match of the 381 evaluated species was not found or did not exist for 73 of the species $(19.2 \%)$. This portion was significantly different among families (contingency tables: $\chi^{2}=42.83, \mathrm{P}<0.0001$ ), with varanidae $(58 \%)$, gekkonidae $(68 \%)$, and agamidae $(72 \%)$ being the families with the lowest number of distribution records available, or with the absence of a climatic station in their limited range of occurrence.

Only 4 species (1.30\% of those with available distribution maps or climatic stations) reached the RAM extreme risk rank (Table 1). The most numerous were species with a serious RAM risk rank-111 (36.04\%)—followed by 106 species with a low RAM risk rank (34.41\%) and 87 species with a moderate RAM risk rank $(28.25 \%)$. We took the mean value of RAM scores if species had this value noted as a range.

Table 1. Species of ornamental reptiles (excluding turtles) with highest potential to establish viable populations in the EU, based on the Risk Assessment model.

\begin{tabular}{cccc}
\hline Species & Family & Risk Score & Risk Rank \\
\hline Diplodactylus vittatus & Gekkonidae & 0.940 & extreme \\
Underwoodisaurus milii & Gekkonidae & 0.920 & extreme \\
Tiliqua scincoides & Scincidae & 0.912 & extreme \\
Intellagama lesueurii & Agamidae & 0.885 & extreme \\
Morelia spilota & Pythonidae & 0.769 & serious \\
Philothamnus semivariegatus & Colubridae & 0.731 & serious \\
Chamaeleo dilepis & Chamaeleonidae & 0.730 & serious \\
Uta stansburiana & Iguanidae & 0.703 & serious \\
Thamnophis sirtalis & Colubridae & 0.662 & serious \\
Chamaeleo calyptratus & Chamaeleonidae & 0.624 & serious \\
Barisia imbricata & Anguidae & $0.582-0.663$ & serious \\
Sauromalus ater & Iguanidae & 0.616 & serious \\
Trioceros bitaeniatus & Chamaeleonidae & 0.586 & serious \\
Cyrtopodion scabrum & Gekkonidae & 0.577 & serious \\
Stenodactylus mauritanicus & Gekkonidae & 0.575 & serious \\
\hline
\end{tabular}

Values of AS-ISK were not evenly distributed (Kolmogorov-Smirnov test: $\mathrm{D}=0.09, \mathrm{P}<0.05$ ), with the greatest portion of species scores from six to nine (Figure 1). However, values of AS-ISK 13 and more were rare and reached by only fifteen species - these can be identified as having the greatest potential to harm native species in the EU (Table 2).

Table 2. Species of ornamental reptiles (excluding turtles) with highest potential to spread and negatively influence nature in the EU, based on AS-ISK (from the Biology/Ecology section only).

\begin{tabular}{ccc}
\hline Species & Family & Risk Score \\
\hline Python sebae & Pythonidae & 16 \\
Malayopython reticulatus & Pythonidae & 16 \\
Osteolaemus tetraspis & Crocodylidae & 15 \\
Agama agama & Agamidae & 14 \\
Eunectes notaeus & Boidae & 14 \\
Varanus salvator & Varanidae & 14 \\
Corallus hortulanus & Boidae & 14 \\
Holcosus undulatus & Teiidae & 14 \\
Hemidactylus frenatus & Gekkonidae & 13 \\
Lepidodactylus lugubris & Gekkonidae & 13 \\
Morelia spilota & Pythonidae & 13 \\
Boa constrictor & Boidae & 13 \\
Nerodia taxispilota & Colubridae & 13 \\
Thamnophis marcianus & Colubridae & 13 \\
Thamnophis sirtalis & Colubridae & 13 \\
\hline
\end{tabular}




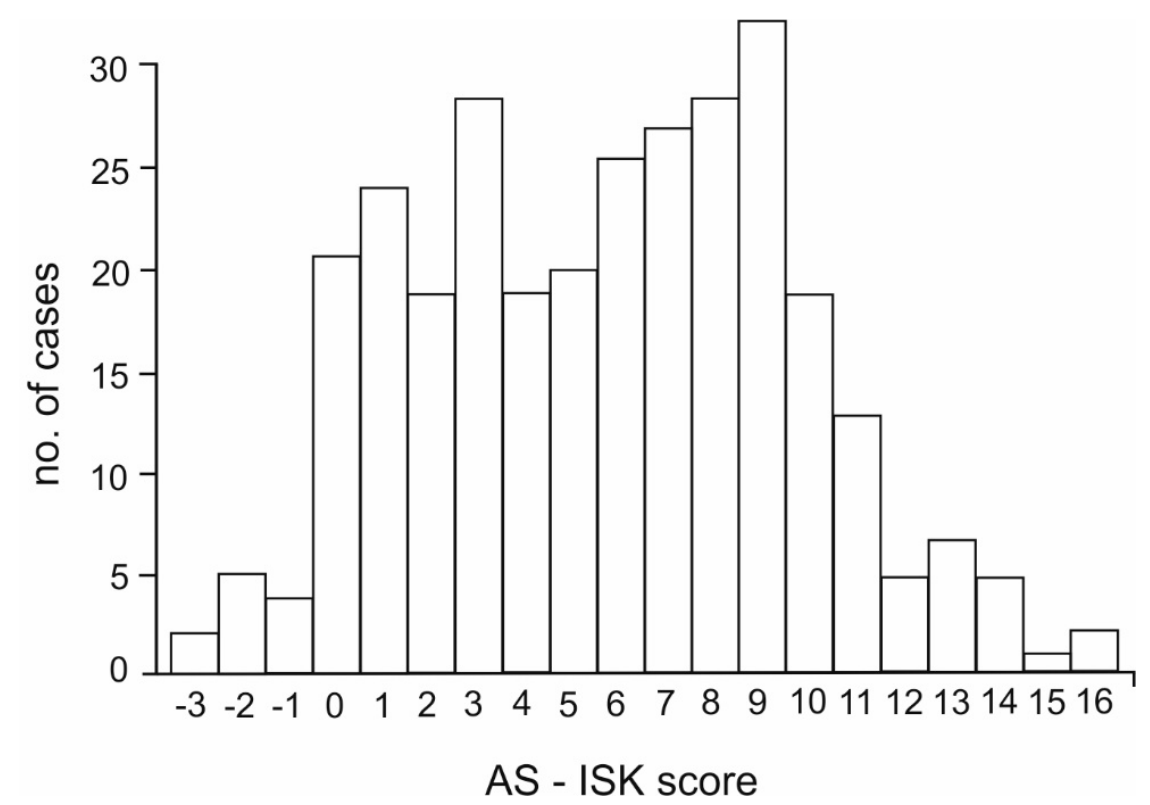

Figure 1. Distribution of AS-ISK score (from Biology/Ecology section only) of ornamental reptile species (excluding turtles) for the EU area.

\section{Discussion}

We used a hierarchical approach to predict species' potential establishment and spread with a negative impact on native ecosystems in the EU. In the first step, we searched for species that are imported and can be released or escape into the wild (transport and introduction). Then, using RAM, we evaluated the establishment potential of these species, and by AS-ISK, their future negative impact on EU nature. This process is advantageous because it overcomes the known problem with risk assessment models-the production of a single unifying factor such as "weediness" or "invasiveness" [33], which often leads to confusion or at least the impossibility of correcting the identification and level of expression of traits involved in the invasion process [34]. On the other hand, the procedure described has its limits. Due to the enormous number of species that were evaluated, particular families were divided among authors. While the calculation of a RAM score is not subjective and the final score is a result of mathematical procedures with given rules, the final value of the AS-ISK score for the same species can differ when species are evaluated by several authors $[35,36]$. We tried to adjust this by holding three meetings of the authors prior to evaluation, where unification of procedure and clarifying specific issues were discussed. It must also be mentioned that we used a non-specific jurisdiction score in the RAM formula, therefore a RAM risk score cannot be viewed as a precise estimation of the probability of establishment, but rather provides a relative ranking of ornamental reptiles traded in the EU.

In contrast to species that invade new areas through accidental pathways, transport of pet-traded species can be controlled and documented [37-39]. Legislative regulations can be based on negative experiences with non-native species already present in the environment, or the ban of such species can be based on predictive models of "invasivity" as a prevention [4]. This approach, which is still precise, deals firstly with the transport step of the invasion process [40]. The second step in the invasion process is introduction [41], which for pet-traded species is usually a deliberate release or unintentional escape from enclosures [12,42]. Therefore, occurrence of non-indigenous species is associated with human activity and invasions are casually linked to demographic data. It has been shown that occurrence of non-native species is associated with the density of human settlement [43], proximity of communications [32], the number of pet shops [44], wealth of inhabitants [45], or the index of urbanization [46]. 
Legislative regulations can effectively ban the trade of some species, however other species replace banned species to satisfy market demands - therefore we cannot expect that the volume of traded reptiles will decrease in the future [47]. Besides abiotic factors, the establishment of non-native species is influenced mostly by the number of individuals that are released into the environment, underpinned by propagule pressure [48]. For example, the potential of certain turtles to become established, which are imported as pets into the EU after the ban of Trachemys scripta, is much higher for many species than for Trachemys scripta [28]. However, their real potential to establish themselves in the EU is limited because of an increased variety of traded species [49], probably resulting in lower numbers of imported individuals for each particular species. Precise data about numbers of imported and exported individuals are still not collected by public authorities in the Czech Republic, therefore we were not able to incorporate propagule pressure into our models.

The impact of non-native species in new environments can be direct or indirect [50]. In all assessed groups of reptiles, we expect rather direct impacts - mainly competition and predation. From the evaluated species, colubrid snake Thamnophis sirtalis and Morelia spilota from the Pythonidae family exhibit high RAM scores (i.e., the ability to become established in large areas of the EU) and at the same time, high AS-ISK scores, and thus from a pan-EU perspective, they represent the most dangerous imported species.

Thamnophis sirtalis is a medium-sized snake with an extensive range from Florida in the United States to the Northwest Territories in Canada [51]. The mode of their reproduction is viviparity [52], which allows reptiles to exist even in cold climates [53]. It is very adaptable and lives in a variety of habitats, including those modified by humans such as pastureland, rural gardens, ponds, drainage canals, and ditches, and is often found near water [51]. Niche overlap is therefore assumed mainly with snakes from the Natricinae subfamily which contains three species living in the EU: Natrix natrix, Natrix maura and Natrix tessellate [54]. Competition for food would be the most probable interaction with these snakes - the food of $T$. sirtalis consists predominantly of anurans, salamanders, and fish [55] which are the main prey of native species of snakes from the genus Natrix [56-58]. A great proportion of amphibians in the EU are endangered and protected, and thus predation is another potential threat to native ecosystems. Due to its resistance to the strongest amphibian toxins, Thamnophis sirtalis can act as a nonselective predator [59]. While members of the family Colubridae are among the most successful reptile invaders in Europe with $14 \%$ of established species among non-native reptiles in European countries [60], Thamnophis sirtalis itself was not established in Europe with known temporary occurrence in Austria, Germany, Great Britain, and Sweden [12]. While there was one case in Germany of an attempt to become established near the city of Dortmund [61], the presence in other countries was random and episodic.

Morelia spilota is a large snake reaching from two to four meters in length from the Australian zoogeographical region, where it is the most widespread python [62]. M. spilota have a broad habitat tolerance-however, occurrence of shrubs and hollow logs is critical for this semiarboreal species $[62,63]$. It is climatically and ecologically adaptable - in Australia it occurs in areas that receive snowfall and is also often found near human habitation [64]. Long-term persistence in adverse conditions can be facilitated by exhibition of maternal care, when females coil around their eggs and guard them until they hatch. Females leave the eggs to bask, and heat obtained from basking is transferred to the clutch. Females may also raise the temperature of the eggs by shivering [65]. The diet of adult snakes consists mainly of mammals, while juveniles consume mammals as well as reptiles [66]. In some parts of the $\mathrm{EU}$, this species may become a top predator. This species may have a lifespan from 15 to 20 years [65], which also increases its invasive potential. Despite snakes from genus Morelia being popular in the pet trade [67] no record of this species outside its native range exists [12].

Other species with high values of AS-ISK evaluated in this article are large animals with the potential to become top predators in their non-native range. However, their RAM scores are low or moderate, suggesting that their potential establishment may be local and mainly in parts of south European countries. At the opposite end, the highest RAM risk scores were for small- to medium-bodied 
lizards. Among them, Australian medium sized lizards Tiliqua scincoides and Intellagama lesueurii also have relatively high AS-ISK scores (11 for both species). The AS-ISK score from part of the model dealing with biological and ecological features was over 10, suggesting potential strong effects on native ecosystems. Known ectothermic vertebrate pests that are already present in the EU, including the frogs Lithobates catesbeianus and Xenopus laevis, obtain this value [27].

A minority of introductions lead to establishment and spread of non-native species. For example, Europe is the continent with the most reptile introductions, but the smallest number of introductions (about 5\%) lead to establishment here [12]. However, we generally underestimate the invasive potential and the negative impact of non-native species [68]. This is especially true for reptiles, which are commonly overlooked in invasion studies [21,22]. We should therefore treat each non-native reptile very carefully and in the EU, pet traded Thamnophis sirtalis, Morelia spilota, Tiliqua scincoides, and Intellagama lesueurii mainly deserve our attention.

Author Contributions: O.K. is authors of original idea. Made conceptualization, supervision and data curation. Also wrote draft of manuscript, creates methodology and visualization of results in form of tables and figures, works with literature resources. Other authors works on data analysis of assigned families in software RAM and AS-ISK and provides review of final version of manuscript draft.

Funding: This research received no external funding.

Acknowledgments: We thank Mary Bomford for her dedication to the question of risk assessment. The English was corrected by Jaroslav Janošek (correcta.cz).

Conflicts of Interest: The authors declare no conflict of interest.

\section{Appendix A}

Table A1. Species of ornamental reptiles (excluding turtles) imported into EU with values of their RAM score (determining establishment potential in EU) and AS-ISK (determining potential to negatively influence nature in the EU).

\begin{tabular}{|c|c|c|c|c|}
\hline Family & Species & $\begin{array}{c}\text { Distribution Map } \\
\text { Available/Presence of } \\
\text { Climate Station }\end{array}$ & RAM & $\begin{array}{c}\text { AS-ISK } \\
\text { (Biology/Ecology } \\
\text { Score Only) }\end{array}$ \\
\hline \multirow[t]{23}{*}{ Chamaleonidae } & Bradypodion setaroi & yes & 0.508 & 4 \\
\hline & Bradypodion thamnobates & yes & 0.508 & 5 \\
\hline & Brookesia betschyi & yes & 0.508 & 3 \\
\hline & Brookesia brygooi & yes & 0.508 & 4 \\
\hline & Brookesia ebenaui & yes & 0.508 & 0 \\
\hline & Brookesia griveaudi & yes & 0.508 & 0 \\
\hline & Brookesia minima & yes & 0.508 & 0 \\
\hline & Brookesia nasus & yes & 0.508 & 0 \\
\hline & Brookesia peyrierasi & yes & 0.508 & 0 \\
\hline & Brookesia stumpffi & yes & 0.508 & 0 \\
\hline & Brookesia therezieni & yes & 0.508 & 0 \\
\hline & Brookesia thieli & yes & 0.508 & 1 \\
\hline & Chamaeleo calyptratus & yes & 0.624 & 8 \\
\hline & Chamaeleo dilepis & yes & 0.731 & 6 \\
\hline & Chamaeleo senegalensis & yes & 0.544 & 3 \\
\hline & Furcifer bifidus & yes & 0.450 & 3 \\
\hline & Furcifer lateralis & yes & 0.450 & 10 \\
\hline & Furcifer oustaleti & yes & 0.450 & 10 \\
\hline & Furcifer pardalis & yes & 0.450 & 8 \\
\hline & Furcifer verrucosus & yes & 0.450 & 10 \\
\hline & Furcifer wilsii & yes & 0.450 & 2 \\
\hline & Rhampholeon acuminatus & no & & \\
\hline & Rhampholeon boulengeri & yes & 0.520 & -1 \\
\hline
\end{tabular}


Table A1. Cont.

\begin{tabular}{|c|c|c|c|c|}
\hline Family & Species & $\begin{array}{c}\text { Distribution Map } \\
\text { Available/Presence of } \\
\text { Climate Station }\end{array}$ & RAM & $\begin{array}{c}\text { AS-ISK } \\
\text { (Biology/Ecology } \\
\text { Score Only) }\end{array}$ \\
\hline & Rhampholeon nchisiensis & no & & \\
\hline & Rhampholeon spectrum & yes & 0.508 & -3 \\
\hline & Rhampholeon spinosus & yes & 0.508 & -3 \\
\hline & Rhampholeon temporalis & yes & 0.508 & -2 \\
\hline & Rhampholeon viridis & yes & 0.508 & 1 \\
\hline & Rieppelon brevicaudatus & yes & 0.508 & 0 \\
\hline & Rieppeleon kerstenii & yes & 0.529 & 1 \\
\hline & Trioceros bitaeniatus & yes & 0.586 & 7 \\
\hline & Trioceros cristatus & yes & 0.450 & 6 \\
\hline & Trioceros deremensis & yes & 0.450 & 3 \\
\hline & Trioceros ellioti & yes & 0.461 & 9 \\
\hline & Trioceros fuelleborni & yes & 0.450 & 7 \\
\hline & Trioceros hoehnelii & yes & 0.528 & 11 \\
\hline & Trioceros jacksonii & yes & 0.542 & 11 \\
\hline & Trioceros melleri & yes & 0.450 & 3 \\
\hline & Trioceros montium & no & & \\
\hline & Trioceros pfefferi & no & & \\
\hline & Trioceros quadricornis & no & & \\
\hline & Trioceros rudis & yes & 0.456 & 8 \\
\hline & Trioceros werneri & yes & 0.450 & 6 \\
\hline & Kinyongia boehmei & yes & 0.450 & 5 \\
\hline & Kinyongia matschiei & yes & 0.450 & 2 \\
\hline & Kinyongia multituberculata & yes & 0.450 & 1 \\
\hline & Kinyongia tavetana & yes & 0.450 & 1 \\
\hline & Kinyongia tenuis & yes & 0.450 & 1 \\
\hline & Kinyongia uthmoelleri & yes & 0.450 & 1 \\
\hline & Calumma boettgeri & yes & 0.450 & 7 \\
\hline & Calumma brevicorne & yes & 0.450 & 3 \\
\hline & Calumma gastrotaenia & yes & 0.450 & 3 \\
\hline & Calumma guillaumeti & no & & \\
\hline & Calumma malthe & yes & 0.450 & 2 \\
\hline & Calumma marojezense & yes & 0.450 & 1 \\
\hline & Calumma nasutum & yes & 0.450 & 4 \\
\hline \multirow[t]{18}{*}{ Gekkonidae } & Aeluroscalabotes felinus & yes & 0.453 & -2 \\
\hline & Blaesodactylus antongilensis & yes & 0.241 & 0 \\
\hline & Blaesodactylus sakalava & yes & 0.241 & 0 \\
\hline & Cnemaspis africana & no & & \\
\hline & Cnemaspis barbouri & no & & \\
\hline & Cnemaspis quattuorseriata & no & & \\
\hline & Coleonyx elegans & yes & 0.220 & 5 \\
\hline & Coleonyx mitratus & yes & 0.218 & 3 \\
\hline & Cyrtodactylus fumosus & no & & \\
\hline & Cyrtopodion scabrum & yes & 0.577 & 8 \\
\hline & Elasmodactylus tetensis & yes & 0.241 & 1 \\
\hline & Elasmodactylus tuberculosus & yes & 0.241 & 3 \\
\hline & Eublepharis macularius & yes & 0.251 & 8 \\
\hline & Geckolepis polylepis & yes & 0.241 & 5 \\
\hline & Gehyra vorax & yes & 0.241 & 0 \\
\hline & Gekko badenii & yes & 0.162 & 4 \\
\hline & Gekko gecko & yes & 0.106 & 6 \\
\hline & Gekko grossmanni & yes & 0.162 & 6 \\
\hline
\end{tabular}


Table A1. Cont.

\begin{tabular}{|c|c|c|c|c|}
\hline Family & Species & $\begin{array}{c}\text { Distribution Map } \\
\text { Available/Presence of } \\
\text { Climate Station }\end{array}$ & RAM & $\begin{array}{c}\text { AS-ISK } \\
\text { (Biology/Ecology } \\
\text { Score Only) }\end{array}$ \\
\hline & Gekko monarchus & no & & \\
\hline & Gekko ulikovskii & yes & 0.162 & 6 \\
\hline & Gekko vittatus & yes & 0.162 & 6 \\
\hline & Gonatodes albogularis & no & & \\
\hline & Goniurosaurus lichtenfelderi & no & & \\
\hline & Hemidactylus ansorgii & no & & \\
\hline & Hemidactylus brookii & no & & \\
\hline & Hemidactylus fasciatus & yes & 0.369 & 9 \\
\hline & Hemidactylus frenatus & yes & 0.370 & 13 \\
\hline & Hemidactylus imbricatus & yes & 0.388 & 11 \\
\hline & Hemidactylus platyurus & no & & \\
\hline & Hemidactylus prashadi & yes & 0.369 & 10 \\
\hline & Hemidactylus ruspolii & no & & \\
\hline & Hemidactylus squamulatus & no & & \\
\hline & Hemidactylus tanganicus & no & & \\
\hline & Hemitheconyx caudicinctus & yes & 0.106 & 2 \\
\hline & Holodactylus africanus & no & & \\
\hline & Homopholis fasciata & yes & 0.502 & 2 \\
\hline & Lepidodactylus lugubris & yes & 0.355 & 13 \\
\hline & Lygodactylus capensis & no & & \\
\hline & Lygodactylus gutturalis & no & & \\
\hline & Lygodactylus kimhowelli & no & & \\
\hline & Lygodactylus klemmeri & yes & 0.162 & 8 \\
\hline & Lygodactylus luteopicturatus & no & & \\
\hline & Lygodactylus miops & yes & 0.162 & 4 \\
\hline & Lygodactylus scheffleri & no & & \\
\hline & Lygodactylus williamsi & yes & 0.127 & 1 \\
\hline & Matoatoa brevipes & yes & 0.162 & 0 \\
\hline & Pachydactylus bibroni & no & & \\
\hline & Pachydactylus rangei & no & & \\
\hline & Paroedura androyensis & yes & 0.453 & 7 \\
\hline & Paroedura bastardi & yes & 0.453 & 5 \\
\hline & Paroedura masobe & yes & 0.453 & 1 \\
\hline & Paroedura picta & yes & 0.453 & 7 \\
\hline & Phelsuma dubia & no & & \\
\hline & Phelsuma laticauda & yes & 0.453 & \\
\hline & Phelsuma lineata & yes & 0.403 & 6 \\
\hline & Phelsuma madagascariensis & yes & 0.403 & 5 \\
\hline & Phelsuma quadriocellata & yes & 0.403 & 3 \\
\hline & Ptychozoon kuhli & no & & \\
\hline & Ptyodactylus guttatus & no & & \\
\hline & Ptyodactylus hasselquistii & yes & 0.061 & 10 \\
\hline & Ptyodactylus ragazzi & no & & \\
\hline & Rhacodactylus auriculatus & yes & 0.106 & 0 \\
\hline & Rhacodactylus chahoua & yes & 0.106 & 3 \\
\hline & Rhacodactylus ciliatus & yes & 0.106 & 1 \\
\hline & Sphaerodactylus sputator & yes & 0.213 & 6 \\
\hline & Stenodactylus petrii & yes & 0.496 & 1 \\
\hline & Stenodactylus sthenodactylus & yes & 0.369 & 5 \\
\hline & Tarentola annularis & yes & 0.327 & 9 \\
\hline & Tarentola delalandii & yes & 0.047 & 1 \\
\hline
\end{tabular}


Table A1. Cont.

\begin{tabular}{|c|c|c|c|c|}
\hline Family & Species & $\begin{array}{l}\text { Distribution Map } \\
\text { Available/Presence of } \\
\text { Climate Station }\end{array}$ & RAM & $\begin{array}{c}\text { AS-ISK } \\
\text { (Biology/Ecology } \\
\text { Score Only) }\end{array}$ \\
\hline \multirow{53}{*}{ Iguanidae } & Tarentola mauretanica & yes & 0.274 & 1 \\
\hline & Teratoscincus roborowskii & yes & 0.213 & 1 \\
\hline & Teratoscincus scincus & yes & 0.213 & 1 \\
\hline & Tropiocolotes steudneri & no & & \\
\hline & Tropiocolotes tripolitanus & yes & 0.505 & 1 \\
\hline & Underwoodisaurus milii & yes & 0.920 & 7 \\
\hline & Ebenavia inunguis & yes & 0.241 & 3 \\
\hline & Uroplatus ebenaui & yes & 0.241 & 6 \\
\hline & Uroplatus guentheri & yes & 0.241 & 2 \\
\hline & Uroplatus fimbriatus & yes & 0.241 & 5 \\
\hline & Uroplatus henkeli & yes & 0.241 & 3 \\
\hline & Uroplatus phantasticus & yes & 0.241 & 6 \\
\hline & Chondrodactylus turneri & no & & \\
\hline & Phyllopezus pollicaris & yes & 0.247 & 8 \\
\hline & Stenodactylus mauritanicus & yes & 0.575 & 1 \\
\hline & Diplodactylus vittatus & yes & 0.940 & 3 \\
\hline & Anolis carolinensis & yes & 0.308 & 11 \\
\hline & Basiliscus vitttatus & yes & 0.226 & 9 \\
\hline & Corytophanes cristatus & yes & 0.271 & 7 \\
\hline & Crotaphytus bicinctores & yes & 0.326 & 5 \\
\hline & Crotaphytus collaris & yes & 0.376 & 5 \\
\hline & Ctenosaura quinquecarinata & no & & \\
\hline & Ctenosaura similis & yes & 0.433 & 7 \\
\hline & Dipsosaurus dorsalis & yes & 0.524 & 2 \\
\hline & Gambelia wislizenii & yes & 0.236 & 5 \\
\hline & Iguana Iguana & yes & 0.371 & 1 \\
\hline & Leiocephalus schreibersi & yes & 0.326 & 0 \\
\hline & Phrynosoma platyrhinos & yes & 0.340 & 3 \\
\hline & Sauromalus ater & yes & 0.616 & -2 \\
\hline & Sceloporus magister & yes & 0.286 & 7 \\
\hline & Sceloporus malachiticus & yes & 0.175 & -1 \\
\hline & Tropidurus hispidus & no & & \\
\hline & Uta stansburiana & yes & 0.703 & 3 \\
\hline & Anolis coelestinus & yes & 0.467 & 4 \\
\hline & Anolis cristatellus & yes & 0.370 & 9 \\
\hline & Anolis cybotes & yes & 0.467 & 7 \\
\hline & Anolis equestris & yes & 0.439 & 8 \\
\hline & Anolis gingivinus & yes & 0.467 & 7 \\
\hline & Anolis hendersoni & yes & 0.467 & 7 \\
\hline & Anolis noblei & yes & 0.467 & 10 \\
\hline & Anolis pogus & yes & 0.431 & 9 \\
\hline & Anolis roquet & yes & 0.467 & 6 \\
\hline & Anolis sagrei & yes & 0.396 & 5 \\
\hline & Basiliscus plumifrons & yes & 0.226 & 2 \\
\hline & Brachylophus fasciatus & yes & 0.470 & 0 \\
\hline & Crotaphytus insularis & yes & 0.206 & 2 \\
\hline & Chalarodon madagascariensis & yes & 0.467 & 4 \\
\hline & Leiocephalus personatus & yes & 0.389 & -2 \\
\hline & Oplurus cyclurus & yes & 0.467 & 0 \\
\hline & Oplurus fierinensis & yes & 0.467 & 0 \\
\hline & Oplurus grandidieri & yes & 0.467 & 2 \\
\hline & Oplurus quadrimaculatus & yes & 0.467 & 0 \\
\hline & Chameleolis barbatus & yes & 0.467 & 4 \\
\hline
\end{tabular}


Table A1. Cont.

\begin{tabular}{|c|c|c|c|c|}
\hline Family & Species & $\begin{array}{c}\text { Distribution Map } \\
\text { Available/Presence of } \\
\text { Climate Station }\end{array}$ & RAM & $\begin{array}{c}\text { AS-ISK } \\
\text { (Biology/Ecology } \\
\text { Score Only) }\end{array}$ \\
\hline \multirow[t]{14}{*}{ Pythonidae } & Aspidites ramsayi & yes & 0.131 & 3 \\
\hline & Bothrochilus boa & yes & 0.060 & 8 \\
\hline & Broghammerus reticulatus & yes & 0.060 & 16 \\
\hline & Broghammerus timoriensis & yes & 0.060 & 2 \\
\hline & Leiopython albertisii & yes & 0.060 & 2 \\
\hline & Liasis mackloti & yes & 0.078 & 9 \\
\hline & Morelia amethistina & yes & 0.078 & 9 \\
\hline & Morelia boeleni & yes & 0.078 & 2 \\
\hline & Morelia spilota & yes & 0.769 & 13 \\
\hline & Morelia viridis & yes & 0.072 & 5 \\
\hline & Python breitensteini & yes & 0.071 & 10 \\
\hline & Python brongersmai & yes & 0.071 & 8 \\
\hline & Python regius & yes & 0.060 & 9 \\
\hline & Python sebae & yes & 0.132 & 16 \\
\hline \multirow[t]{8}{*}{ Boidae } & Calabaria reinhardtii & yes & 0.084 & 10 \\
\hline & Acrantophis dumerili & yes & 0.084 & 9 \\
\hline & Epicrates cenchria & yes & 0.060 & 8 \\
\hline & Eunectes notaeus & yes & 0.206 & 14 \\
\hline & Corallus caninus & yes & 0.059 & 6 \\
\hline & Corallus hortulanus & yes & 0.103 & 14 \\
\hline & Gongylophis colubrinus & no & & \\
\hline & Boa constrictor & yes & 0.171 & 13 \\
\hline Crocodylidae & Osteolaemus tetraspis & yes & 0.201 & 15 \\
\hline Alligatoridae & Paleosuchus palpebrosus & yes & 0.096 & 12 \\
\hline Anguidae & Barisia imbricata & yes & $0.58-0.66$ & 2 \\
\hline \multirow[t]{29}{*}{ Agamidae } & Acanthocercus atricollis & yes & 0.397 & 6 \\
\hline & Agama aculeata & yes & 0.465 & 5 \\
\hline & Agama agama & yes & 0.208 & 14 \\
\hline & Agama doriae & yes & 0.403 & 0 \\
\hline & Hydrosaurus amboinensis & yes & 0.351 & 4 \\
\hline & Hydrosaurus weberi & yes & 0.351 & 2 \\
\hline & Japalura tricarinata & yes & 0.462 & 2 \\
\hline & Leiolepis belliana & yes & 0.113 & 1 \\
\hline & Leiolepis guttata & yes & 0.113 & 1 \\
\hline & Leiolepis reevesii & yes & 0.113 & -2 \\
\hline & Physignathus cocincinus & yes & 0.208 & 4 \\
\hline & Intellagama lesueurii & yes & 0.885 & 11 \\
\hline & Pogona vitticeps & yes & 0.151 & 10 \\
\hline & Pseudotrapelus sinaitus & yes & 0.087 & 7 \\
\hline & Chlamydosaurus kingi & yes & 0.116 & 6 \\
\hline & Trapelus savignii & yes & 0.429 & 5 \\
\hline & Acanthosaura lepidogaster & yes & 0.455 & 4 \\
\hline & Uromastyx acanthinura & yes & 0.073 & 6 \\
\hline & Uromastyx benti & yes & 0.058 & -1 \\
\hline & Draco maculatus & yes & 0.455 & 3 \\
\hline & Calotes jubatus & yes & 0.455 & 2 \\
\hline & Japalura splendida & no & & \\
\hline & Uromastyx geyri & no & & \\
\hline & Uromastyx dispar & no & & \\
\hline & Uromastyx ornata & no & & \\
\hline & Acanthosaura capra & no & & \\
\hline & Draco volans & no & & \\
\hline & Calotes emma & no & & \\
\hline & Gonocephalus chamaeleontinus & no & & \\
\hline
\end{tabular}


Table A1. Cont.

\begin{tabular}{|c|c|c|c|c|}
\hline Family & Species & $\begin{array}{c}\text { Distribution Map } \\
\text { Available/Presence of } \\
\text { Climate Station }\end{array}$ & RAM & $\begin{array}{c}\text { AS-ISK } \\
\text { (Biology/Ecology } \\
\text { Score Only) }\end{array}$ \\
\hline \multirow[t]{22}{*}{ Scincidae } & Acontias percivalii & yes & 0.279 & 9 \\
\hline & Bellatorias frerei & yes & 0.131 & 9 \\
\hline & Egernia depressa & yes & 0.126 & 9 \\
\hline & Corucia zebrata & yes & 0.064 & 1 \\
\hline & Chalcides sexlineatus & yes & 0.278 & 11 \\
\hline & Lamprolepis smaragdina & yes & 0.281 & 5 \\
\hline & Mochlus sundevalli & yes & 0.416 & 9 \\
\hline & Mabuya multifasciata & yes & 0.324 & 11 \\
\hline & Mabuya quinquetaeniata & no & & \\
\hline & Lepidothyris fernandi & yes & 0.411 & 9 \\
\hline & Scincus scincus & yes & 0.356 & 9 \\
\hline & Trachylepis affinis & no & & \\
\hline & Trachylepis elegans & yes & 0.293 & 7 \\
\hline & Trachylepis margaritifera & yes & 0.293 & 8 \\
\hline & Trachylepis perrotetii & no & & \\
\hline & Tiliqua gigas & yes & 0.226 & 10 \\
\hline & Tiliqua scincoides & yes & 0.912 & 11 \\
\hline & Tribolonotus gracilis & yes & 0.064 & 9 \\
\hline & Tropidophorus baconi & no & & \\
\hline & Eumeces schneideri & yes & 0.438 & 7 \\
\hline & Eumeces algeriensis & yes & 0.405 & 10 \\
\hline & Voeltzkowia rubrocaudata & yes & 0.264 & 9 \\
\hline \multirow[t]{10}{*}{ Gerrhosauridae } & Zonosaurus karsteni & yes & $0.018-0.271$ & 8 \\
\hline & Zonosaurus laticaudatus & yes & $0.018-0.271$ & 10 \\
\hline & Zonosaurus madagascariensis & yes & $0.018-0.271$ & 6 \\
\hline & Zonosaurus maximus & yes & $0.018-0.271$ & 7 \\
\hline & Zonosaurus ornatus & yes & $0.018-0.271$ & 10 \\
\hline & Zonosaurus quadrilineatus & yes & $0.018-0.271$ & 6 \\
\hline & Gerrhosaurus flavigularis & no & & \\
\hline & Gerrhosaurus major & yes & $0.036-0.430$ & 9 \\
\hline & Gerrhosaurus nigrolineatus & no & & \\
\hline & Tracheloptychus petersi & yes & $0.018-0.271$ & 8 \\
\hline \multirow[t]{12}{*}{ Varanidae } & Varanus acanthurus & yes & 0.119 & 9 \\
\hline & Varanus beccarii & no & & \\
\hline & Varanus boehmei & yes & 0.119 & 9 \\
\hline & Varanus exanthematicus & yes & 0.037 & 9 \\
\hline & Varanus jobiensis & yes & 0.119 & 9 \\
\hline & Varanus macraei & no & & \\
\hline & Varanus melinus & no & & \\
\hline & Varanus prasinus & yes & 0.119 & 9 \\
\hline & Varanus rudicolis & no & & \\
\hline & Varanus salvator & yes & 0.119 & 14 \\
\hline & Varanus timorensis & yes & 0.119 & 8 \\
\hline & Varanus yuwonoi & no & & \\
\hline \multirow[t]{6}{*}{ Lacertidae } & Acanthodactylus longipes & yes & 0.458 & 11 \\
\hline & Adolfus jacksoni & yes & 0.391 & 3 \\
\hline & Heliobolus spekii & yes & 0.474 & 3 \\
\hline & Holaspis guentheri & yes & 0.325 & 5 \\
\hline & Latastia longicaudata & yes & 0.492 & 10 \\
\hline & Takydromus sexlineatus & yes & 0.325 & 5 \\
\hline \multirow[t]{4}{*}{ Teiidae } & Ameiva ameiva & no & & \\
\hline & Holcosus undulatus & yes & 0.368 & 14 \\
\hline & Aspidoscelis deppei & yes & 0.366 & 3 \\
\hline & Cnemidophorus lemniscatus & no & & \\
\hline
\end{tabular}


Table A1. Cont.

\begin{tabular}{|c|c|c|c|c|}
\hline Family & Species & $\begin{array}{c}\text { Distribution Map } \\
\text { Available/Presence of } \\
\text { Climate Station }\end{array}$ & RAM & $\begin{array}{c}\text { AS-ISK } \\
\text { (Biology/Ecology } \\
\text { Score Only) }\end{array}$ \\
\hline \multirow{7}{*}{ Cordylidae } & Tupinambis merianae & yes & 0.150 & 12 \\
\hline & Tupinambis rufescens & yes & 0.145 & 12 \\
\hline & Cordylus beraduccii & yes & $0.018-0.271$ & 3 \\
\hline & Cordylus tropidosternum & yes & $0.018-0.271$ & 3 \\
\hline & Platysaurus guttatus & no & & \\
\hline & Platysaurus intermedius & yes & $0.019-0.275$ & 5 \\
\hline & Platysaurus torquatus & yes & $0.018-0.271$ & 3 \\
\hline \multirow[t]{43}{*}{ Colubridae } & Ahaetulla nasuta & yes & 0.056 & 10 \\
\hline & Ahaetulla prasina & yes & 0.056 & 8 \\
\hline & Coelognathus helena & no & & \\
\hline & Coelognathus radiatus & no & & \\
\hline & Chrysopelea ornata & no & & \\
\hline & Boiga cynodon & yes & 0.075 & 8 \\
\hline & Boiga dendrophila & no & & \\
\hline & Coluber constrictor & yes & 0.067 & 12 \\
\hline & Cyclophiops major & yes & 0.060 & 8 \\
\hline & Dasypeltis fasciata & yes & 0.115 & 6 \\
\hline & Dasypeltis medici & yes & 0.157 & 8 \\
\hline & Dasypeltis scabra & yes & 0.401 & 8 \\
\hline & Dromicodryas bernieri & yes & 0.134 & 7 \\
\hline & Elaphe bimaculata & yes & 0.099 & 11 \\
\hline & Elaphe carinata & no & & \\
\hline & Erpeton tentaculatum & yes & 0.056 & 8 \\
\hline & Euprepiophis mandarinus & yes & 0.332 & 8 \\
\hline & Gonyosoma oxycephala & yes & 0.342 & 4 \\
\hline & Homalopsis buccata & yes & 0.134 & 7 \\
\hline & Lampropeltis alterna & yes & 0.073 & 8 \\
\hline & Lampropeltis getula & yes & 0.122 & 11 \\
\hline & Lampropeltis pyromelana & yes & 0.116 & 8 \\
\hline & Lampropeltis triangulum & no & & \\
\hline & Lamprophis fuliginosus & yes & 0.482 & 9 \\
\hline & Langaha madagascariensis & yes & 0.134 & 7 \\
\hline & Leioheterodonn geayi & yes & 0.134 & 8 \\
\hline & $\begin{array}{l}\text { Leioheterodon } \\
\text { madagascariensis }\end{array}$ & yes & 0.134 & 7 \\
\hline & Leioheterodon modestus & yes & 0.134 & 7 \\
\hline & Liophidium chabaudi & yes & 0.134 & 6 \\
\hline & Madagascarophis citrinus & no & & \\
\hline & Madagascarophis colubrinus & yes & 0.134 & 8 \\
\hline & Nerodia taxispilota & yes & 0.100 & 13 \\
\hline & Oligodon chinensis & yes & 0.151 & 9 \\
\hline & Oligodon formosanus & yes & 0.135 & 6 \\
\hline & Oocatochus rufodorsatus & yes & 0.073 & 10 \\
\hline & Opheodrys aestivus & yes & 0.139 & 9 \\
\hline & Oreocryptophis porphyracea & no & & \\
\hline & Orthriophis moellendorffi & yes & 0.290 & 6 \\
\hline & Orthriophis taeniurus friesi & no & & \\
\hline & Psammophis mossambicus & yes & 0.140 & 9 \\
\hline & Psammophylax multisquamis & no & & \\
\hline & Pseudelaphe flavirufa & yes & 0.059 & 6 \\
\hline & Rhadinophis frenatum & yes & 0.345 & 6 \\
\hline
\end{tabular}


Table A1. Cont.

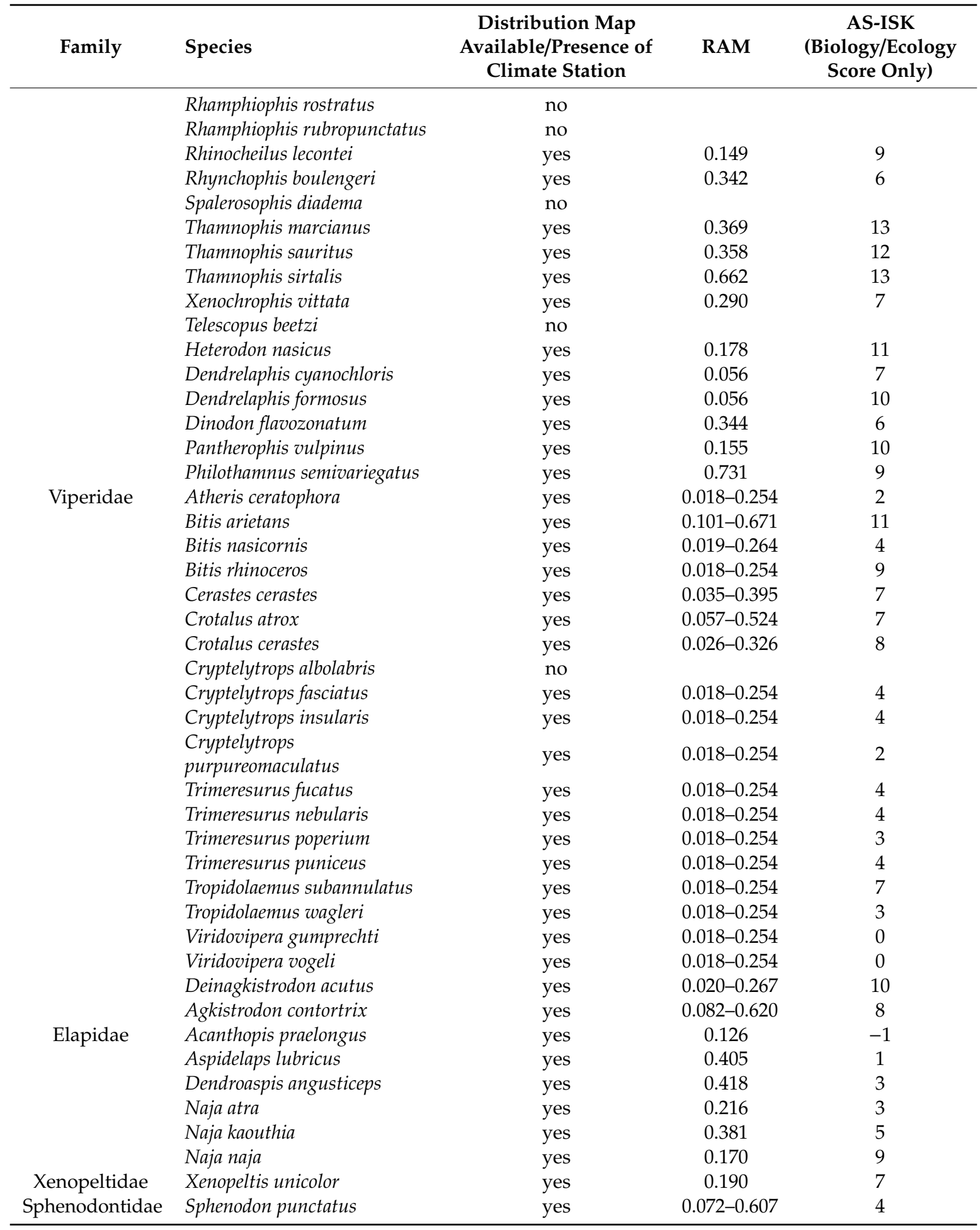

\section{References}

1. Dukes, J.S.; Mooney, H.A. Does global change increase the success of biological invaders? Trends Ecol. Evol. 1999, 14, 135-139. [CrossRef]

2. Strayer, D.L.; Evinver, V.T.; Jeschke, J.M.; Pace, M.L. Understanding the long-term effects of species invasions. Trends Ecol. Evol. 2006, 21, 645-651. [CrossRef] [PubMed] 
3. Ricciardi, A. Are modern biological invasions an unprecedented form of global change? Conserv. Biol. 2007, 21, 329-336. [CrossRef] [PubMed]

4. Hulme, P.E. Beyond control: Wider implications for the management of biological invasions. J. Appl. Ecol. 2006, 43, 835-847. [CrossRef]

5. Pimentel, D.; Zuniga, R.; Morrison, D. Update on the environmental and economic costs associated with alien-invasive species in the United States. Ecol. Econ. 2005, 52, 273-288. [CrossRef]

6. Puth, L.M.; Post, D.M. Studying invasion: Have we missed the boat? Ecol. Lett. 2005, 8, 715-721. [CrossRef]

7. Hulme, P.E.; Pyšek, P.; Nentwig, W.; Vila, M. Will threat of biologicalinvasions unite the European Union? Science 2009, 324, 40-41. [CrossRef] [PubMed]

8. Pitt, W.C.; Witmer, G.W. Invasive vertebrate species and the challenges of management. In Proceedings of the 26th Vertebrate Pest Conference, Philadelphia, PA, USA, 3-6 March 2015; pp. 12-14.

9. Elvira, B.; Almodovar, A. Freshwater fish introductions in Spain: Facts and figures at the beginning of the 21st century. J. Fish Biol. 2005, 59, 323-331. [CrossRef]

10. Jeschke, J.M.; Strayer, D.L. Invasion success of vertebrates in Europe and North America. Proc. Natl. Acad. Sci. USA 2015, 102, 7198-7202. [CrossRef] [PubMed]

11. Kraus, F. Impacts from invasive reptiles and amphibians. Annu. Rev. Ecol. Evol. Syst. 2015, 46, 75-97. [CrossRef]

12. Kraus, F. Alien Reptiles and Amphibians: A Scientific Compedium and Analysis; Springer: Dordrecht, The Netherland, 2009.

13. Albert, A.; Bulcroft, K. Pets and urban life. Anthrozoos 2015, 28, 9-25. [CrossRef]

14. Copping, J. Reptiles now more Popular Pets than Dogs. The Telegraph. 22 November 2008. Available online: https://www.telegraph.co.uk/news/earth/3500882/Reptiles-now-more-popular-pets-thandogs.html (accessed on 10 April 2019).

15. Virata, J. Pet Reptile Product Sales Reach \$383 million in 2016. Reptiles Magazine. 17 December 2017. Available online: http://www.reptilesmagazine.com/Pet-Reptile-Product-Sales-Reach-383-Million-In-2016/ (accessed on 10 April 2019).

16. Rodda, G.H.; Fritts, T.H.; Chiszar, D. The disappearance of Guam's wildlife. Bioscience 1997, 47, 565-574. [CrossRef]

17. Telecky, T.M. United States import and export of live turtles and tortoises. Turt. Tortoise Newsl. 2001, 4, 8-13.

18. Cadi, A.; Joly, P. Competition for basking places between the endangered European pond turtle (Emys orbicularis galloitalica) and the introduced red-eared turtle (Trachemys scripta elegans). Can. J. Zool. 2003, 81, 1392-1398. [CrossRef]

19. Cadi, A.; Joly, P. Impact of the introduction of the red-eared slider (Trachemys scripta elegans) on survival rates of the European pond turtle (Emys orbicularis). Biodivers. Conserv. 2004, 13, 2511-2518. [CrossRef]

20. Teillac-Deschamps, P.; Prevot-Julliard, A.C. Impact of exotic slider turtles on freshwater communities: An experimental approach. In First European Congress of Conservation Biology; Book Ofabstracts; Society for Conservation Biology: Heger, Germany, 2006; pp. 162-163.

21. Bomford, M.; Kraus, F.; Barry, S.C.; Lawrence, E. Predicting establishment success for alien reptiles and amphibians: A role for climate matching. Biol. Invasions 2009, 11, 713-724. [CrossRef]

22. Henderson, W.; Bomford, M.; Cassey, P. Managing the risk of exotic vertebrates incursions in Australia. Wildl. Res. 2011, 38, 501-508. [CrossRef]

23. Ernst, R.; Massemin, D.; Kowarik, I. Non-invasive invaders from the Caribbean: The status of Johnstone's Whistling frog (Eleutherodactylus johnstonei) ten years after its introduction to Western French Guiana. Biol. Invasions 2011, 13, 1767-1777. [CrossRef]

24. Ploeg, A. The volume of the ornamental fish trade, International transport of live fish in the ornamental aquatic industry. Ornam. Fish Int. J. 2007, 2, 48-61.

25. Patoka, J.; Kalous, L.; Kopecký, O. Imports of ornamental crayfish: The firstdecade from the Czech Republic'ys perspective. Knowl. Manag. Aquat. Ecosyst. 2015, 416, 4. [CrossRef]

26. Kalous, L. (Naše) nepůvodní a invazní druhy ryb. Živa 2018, 5, $266-267$.

27. Kopecký, O.; Patoka, J.; Kalous, L. Establishment risk and potential invasiveness of the selected exotic amphibians from pet trade in the European Union. J. Nat. Conserv. 2016, 31, 22-28. [CrossRef]

28. Kopecký, O.; Kalous, L.; Patoka, J. Establishment risk from pet-trade freshwater turtles in the European Union. Knowl. Manag. Aquat. Ecosyst. 2013, 410, 2. [CrossRef] 
29. Nentwig, W.; Kühnel, E.; Bacher, S. A generic impact-scoring systém applied to alien mammals in Europe. Conserv. Biol. 2010, 24, 302-311. [CrossRef] [PubMed]

30. Bomford, M. Risk Assessment Models for Establishment of Exotic Vertebrates in Australia and New Zealand; Invasive Animals Cooperative Research Centre: Canberra, Australia, 2008.

31. Copp, G.H.; Villizzi, L.; Tidbury, H.; Stebbing, P.D.; Tarkan, A.S.; Miossec, L.; Goulletquer, P. Development of a generic decision-support tool for identifying potentially invasive aquatic taxa: AS-ISK. Manag. Biol. Invasions 2016, 7, 343-350. [CrossRef]

32. Copp, G.H.; Bianco, P.G.; Bogutskaya, N.G.; Eros, T.; Falka, I.; Ferreira, M.T. To be, or not to be, a non-native freshwater fish? J. Appl. Ichtyol. 2005, 21, 242-262. [CrossRef]

33. Kumschick, S.; Richardson, D.M. Species-based risk assessments forbiological invasions: Advances and challenges. Divers. Distrib. 2013, 19, 1095-1105. [CrossRef]

34. Cassey, P.; Blackburn, T.M.; Jones, K.E.; Lockwood, J.L. Mistakes in theanalysis of exotic species establishment: Source pool designation andcorrelates of introduction success among parrots (Aves: Psittaciformes) of theworld. J. Biogeogr. 2004, 31, 277-284. [CrossRef]

35. Copp, G.H.; Vilizzi, L.; Mumford, J.; Fenwick, G.V.; Godard, M.J.; Gozlan, R.E. Calibration of FISK, an Invasiveness Screening Tool for Nonnative Freshwater Fish. Risk Anal. 2009, 29, 457-467. [CrossRef]

36. Vilizzi, L.; Copp, G.H.; Adamovich, B.; Almeida, D.; Chan, J.; Davison, P.I.; Dembski, S.; Ekmekçi, F.G.; Ferincz, Á.; Forneck, S.C.; et al. A global review and meta-analysis of applications of the freshwater Fish Invasiveness Screening Kit. Rev. Fish Biol. Fish. 2019, 29, 529-568. [CrossRef]

37. Ficetola, G.F.; Thuiller, W.; Miaud, C. Prediction and validation of thepotential global distribution of a problematic alien invasive species-The American bullfrog. Divers. Distrib. 2007, 13, 476-485. [CrossRef]

38. Kolar, C.S.; Lodge, D.M. Progress in invasion biology: Predictinginvaders. Trends Ecol. Evol. 2001, 16, 199-204. [CrossRef]

39. Poessel, S.A.; Beard, K.H.; Callahan, C.M.; Ferreira, R.B.; Stevenson, E.T. Biotic acceptance in introduced amphibians and reptiles in Europe and North America. Glob. Ecol. Biogeogr. 2013, 22, 192-201. [CrossRef]

40. Dick, J.A.T.; Laverty, C.; Lennon, J.J.; Barrios-O’Neill, D.; Mensink, P.J.; Britton, J.R.; Medoc, V.; Boets, P.; Alexander, M.E.; Taylor, N.G.; et al. Invader Relative Impact Potential: A new metric to understand and predict the ecological impacts of existing, emerging and future invasive alien species. J. Appl. Ecol. 2017, 54, 1259-1267. [CrossRef]

41. Blackburn, T.M.; Pyšek, P.; Bacher, S.; Carlton, J.T.; Duncan, R.P.; Jarošík, V.; Wilson, J.R.U.; Richardson, D.M. A proposed unified framework for biological invasions. Trends Ecol. Evol. 2011, 26, 333-339. [CrossRef]

42. Patoka, J.; Petrtýl, M.; Kalous, L. Garden ponds as potential introduction pathway of ornamental crayfish. Knowl. Manag. Aquat. Ecosyst. 2014, 414, 13. [CrossRef]

43. Semmens, B.X.; Buhle, E.R.; Salomon, A.K.; Pattengill-Semmens, C.V. A hotspot of non-native marine fish: Evidence for the aquarium trade as an invasion pathway. Mar. Ecol. Prog. Ser. 2004, 266, 239-244. [CrossRef]

44. Duggan, I.C.; Rixon, C.A.M.; MacIsaac, H.J. Popularity and propagule pressure: Determinants of introduction and establishment of aquarium fish. Biol. Invasions 2006, 8, 393-398. [CrossRef]

45. Pyšek, P.; Jarošík, V.; Hulme, P.E.; Pergl, J.; Hejda, M. A global assessment of invasive plant impacts on resident species, communities and ecosystems: The interaction of impact measures, invading species' traits and environment. Glob. Chang. Biol. 2012, 18, 1725-1737. [CrossRef]

46. Copp, G.H.; Vilizzi, L.; Gozlan, R.E. The demography of introduction pathways, propagule pressure and occurrences of non-native freshwater fish in England. Aquat. Conserv. Mar. Freshw. Ecosyst. 2010, 20, 595-601. [CrossRef]

47. Herrel, A.; van der Meijden, A. An analysis of the live reptile andamphibian trade in the USA compared to the global trade in endangeredspecies. Herpetol. J. 2014, 24, 103-110.

48. Williamson, M.; Fitter, A. The characters of successful invaders. Biol. Conserv. 1996, 78, 163-170. [CrossRef]

49. Bush, E.R.; Baker, S.E.; MacDonald, D.W. Global trade in exotic pets 2006-2012. Conserv. Biol. 2014, 28, 663-676. [CrossRef] [PubMed]

50. Goodenough, A.E. Are the ecological impacts of alien speciesmisrepresented? A review of the native good, alien bad philosophy. Commun. Ecol. 2010, 11, 13-21. [CrossRef]

51. Frost, D.R.; Hammerson, G.A.; Santos-Barrera, G. Thamnophis Sirtalis; The IUCN Red List of Threatened Species: London, UK, 2015. [CrossRef] 
52. Blackburn, D.G. Review: Discrepant usage of the term "ovoviviparity" in the herpetological literature. Herpetol. J. 1994, 4, 65-72.

53. Shine, R. Does Viviparity Evolve in Cold Climate Reptiles Because Pregnant Females Maintain Stable (Not High) Body Temperatures? Evolution 2004, 28, 1809-1818. [CrossRef]

54. Speybroeck, J.; Crochet, P.-A. Species list of the European herpetofauna-A tentative update. Podarcis 2007, 8, 8-14.

55. Edgehouse, M.J. Garter Snake (Thamnophis) Natural History: Food Habits and Interspecific Aggression. Ph.D. Thesis, Utah State University, Logan, UT, USA, 2008.

56. Luiselli, L.; Filippi, E.; Capula, M. Geographic variation in diet composition of the Grass Snake (Natrix natrix) along the mainland and an island of Italy: The effect of habitat type and interference with potential competitors. Herpetol. J. 2005, 15, 221-230.

57. Luiselli, L.; Capizzi, D.; Filippi, E.; Anibaldi, C.; Rugiero, L.; Capula, M. Comparative Diets of Three Populations of an Aquatic Snake (Natrix Tessellata, Colubridae) from Mediterranean Streams with Different Hydric Regimes. Copeia 2007, 2, 426-435. [CrossRef]

58. Santos, X.; González-Solís, J.; Llorente, G.A. Variation in the diet of the viperine snake Natrix maura in relation to prey availability. Ecography 2000, 23, 185-192. [CrossRef]

59. Brodie, E.D., III; Brodie, E.D., Jr. Tetrodotoxin resistance in garter snakes: An evolutionary response of predators to dangerous prey. Evolution 1990, 44, 651-659. [CrossRef]

60. Kark, S.; Solarz, W.; Chiron, F.; Clergeau, P.; Shirley, S. Alien birds, amphibians and reptiles of Europe. In Handbook of Alien Species in Europe; Springer: Berlin/Heidelberg, Germany, 2009; pp. 105-118.

61. Münch, D. Ausgesetzte Amphibien-Und Reptilienarten in Dortmund und weitere herpetologische Kurzmitteilungen. Dortm. Beitr. Landeskd. Naturwissenschaftliche Mitt. 1992, 26, 34-45.

62. Tallowin, O.; Parker, F.; O'Shea, M.; Vanderduys, E.; Wilson, S.; Shea, G.; Hobson, R. Morelia Spilota; The IUCN Red List of Threatened Species: London, UK, 2017. [CrossRef]

63. Pearson, D.; Shine, R.; Williams, A. Spatial ecology of a threatened python (Morelia spilota imbricata) and the effects of anthropogenic habitat change. Aust. Ecol. 2005, 30, 261-274. [CrossRef]

64. Shine, R.; Fitzgerald, M. Large snakes in a mosaic rural landscape: The ecology of carpet pythons Morelia spilota (Serpentes: Pythonidae) in coastal eastern Australia. Biol. Conserv. 1996, 76, 113-122. [CrossRef]

65. Wilson, S.; Swan, G. A Complete Guide to Reptiles of Australia; Reed New Holland Publishers: Chatswood, Australia, 2010.

66. Slip, D.; Shine, R. Habitat Use, Movements and Activity Patterns of Free-Ranging Diamond Pythons, Morelia-Spilota-Spilota (Serpentes, Boidae)_A Radiotelemetric Study. Wildl. Res. 1988, 15, 515-531. [CrossRef]

67. Wilson, D.; Heinsohn, R. Geographic range, population structure and conservation status of the green python (Morelia viridis), a popular snake in the captive pet trade. Aust. J. Zool. 2007, 55, 147-154. [CrossRef]

68. Jaric, I.; Civjanovic, G. The Tens Rule in Invasion Biology: Measure of a True Impactor Our Lack of Knowledge and Understanding? Environ. Manag. 2012, 50, 79-981. [CrossRef]

(C) 2019 by the authors. Licensee MDPI, Basel, Switzerland. This article is an open access article distributed under the terms and conditions of the Creative Commons Attribution (CC BY) license (http://creativecommons.org/licenses/by/4.0/). 